\title{
九州地方中南部におけるフィリピン海スラブ内地震活動
}

\author{
京都大学大学院理学研究科地球惑星科学専攻地球物理学教室* 岡 本 響 ${ }^{\dagger}$ \\ 京都大学大学院理学研究科附属地球熱学研究施設火山研究センター** 大倉 敬 宏 \\ 東京大学 地震研究所 地球ダイナミクス部門*** 瀬 野 徹三
}

\section{Seismicity within the Philippine Sea Slab in the Central and Southern Kyushu, Japan}

\author{
Kyo OKAMOTo ${ }^{\dagger}$ \\ Department of Geophysics, Division of Earth and Planetary Science, Graduate School of Science, \\ Kyoto University, Kitashirakawa Oiwake-cho, Sakyo-ku, Kyoto 606-8502, Japan

\section{Takahiro OHKURA} \\ Aso Volcanological Laboratory, Institute for Geothermal Sciences, Graduate School of Science, \\ Kyoto University, Kawayo 5280, Minamiaso-mura, Kumamoto 869-1404, Japan
}

\section{Tetsuzo SENO}

Geodynamics Division, Earthquake Research Institute, University of Tokyo, Yayoi 1-1-1, Bunkyo-ku, Tokyo 113-0032, Japan

(Received May 15, 2006; Accepted September 29, 2008)

\begin{abstract}
Since dehydration embrittlement of oceanic crust and mantle in a subducting slab is considered to be responsible for the occurrence of intermediate-depth earthquakes, it is very important to know the location of these earthquakes; within the oceanic crust and/or the slab mantle. Usually in Southwest Japan, crustal earthquakes in the Philippine Sea plate (PHS) are associated with deep low frequency tremor. In order to determine the locations of intraslab earthquakes of the PHS in central and southern Kyushu, Japan, we examined existence of seismic waves guided by the oceanic crust, and we applied the Double-Difference method for relocating the interplate and intraslab earthquakes occurring in the study area. The results are as follows. (1) Throughout the study area, waveform analysis and hypocenter determination show that intraslab earthquakes occurred within the slab mantle. (2) From waveform analysis, we found that in the northern part of the study area, where no deep low frequency tremor is observed, some intraslab earthquakes occurred within the oceanic crust. (3) It is not clear whether earthquakes occurred within the oceanic crust in the southern part of the study area. Therefore, central Kyushu is unusual region in Southwest Japan, where dehydration takes place in the oceanic crust but it is not associated with deep low frequency tremor above the slab.
\end{abstract}

Key words: Philippine Sea slab, Dehydration embrittlement, Guided waves, Double-Difference hypocenter determination, Deep low frequency tremor

\footnotetext{
* =606-8502 京都市左京区北白川追分町

** = 869-1404 熊本県阿蘇郡南阿蘇村河陽 5280

*** $=113-0032$ 東京都文京区弥生 1-1-1
}

$\dagger$ 現所属：西日本電信電話株式会社・技術革新部 研究開発セン夕

Research and Development Center, Technology Innovation Department, NTT WEST. 


\section{§1.はじめに}

スラブ近傍の地震が発生している場所を明らかにする ことは, 沈み込み帯のダイナミクス, 特に水の挙動を考 えるうえで重要である。それらの地震の多くは含水鉱物 の脱水に伴う脆性不安定によって引き起こされると考え られている。ささらに，発生した水はプレート境界地震， 深部低周波微動といったプレート境界付近の地震活動に 影響を与える．そのため，水の起源がどこであるかを知 ることは，沈み込み帯全域の地震活動を解明する手がか りとなる.

これまでに日本列島下に沈み込むフィリピン海プレー トに関する地震活動やスラブ形状についてさまざまな研 究がなされている。 そのうち, 関東や東海, 中国四国地 方の地震活動や沈み込むスラブの形状についてはかなり 詳しく調べられている。これらの地域では，スラブが低 角に沈み込んでおり [例えば, 石川 (2001)]，紀伊半島下 には稍深発地震面の二層構造が見つかっており，二重深 発地震面 [Seno et al. (2001)], あるいは断裂したスラブ の重なり [三好・石橋 (2004)］と解釈されている.

一方，九州地方では，他のフィリピン海プレートの沈 み込み帯とは異なり，スラブは高角に沈み込んでいる。 また，スラブの形状については，最深地震の分布や各深 度での地震活動度が不連続に変わることから，スラブの 断裂やブロック構造が指摘されている [例えば，長宗・ 田代(1989), 角田 ・他 (1991，1995), 石原 ・吉田 (1992)]。しかし, 前述の地域や太平洋プレートの沈み込 む東北地方に比べると地震活動やスラブ形状の解明は遅 れていたといわざるをえない。これは，高感度地震観測 網の展開が他地域に比べて遅れていたことや，スラブの 沈み込み角度が急であることが大きな理由だと思われ る.

ところで，スラブ形状を地震面の位置のみによって推 定する場合には注意が必要である，スラブ内地震は，沈 み込む海洋地殼内で起こるものと，マントル内で起こる あのとに分けられる [例えば, Yamasaki and Seno (2003)] (以下前者をスラブ地款地震, 後者をスラブマン トル地震と呼ぶ）。スラブ地殼地震が起こっておらずス ラブマントル地震のみが起こっている場合には，スラブ 上面が実際より屯深く見積もられてしまう [Hori (2006)]. また，地域によって活動の頻度や位置が異なる 場合では，スラブの形状の地域差（ブロック構造，断裂 など）として認識されてしまう可能性がある. 九州地方 のスラブの形状は主としてスラブ内地震活動によって推 定されているが，九州地方において，スラブ内地震がス ラブのよ゙こで起こっているのかはよくわかっておらず, これを知ることは非常に重要である.
一方, Obara (2002) は深部低周波微動がトラフ軸に 平行に分布することを発見した (Fig. 1 参照). 深部低周 波微動之は，周波数が数 $\mathrm{Hz}$ 程度で振幅の非常に小さな 波動が断続的に数時間から数週間続く現象である。その 震源の深さは $30 \mathrm{~km}$ 程度であり, プレート境界むしく は大陸モホ面付近で発生していると考えられる。低周波 微動の震源位置がスラブ内地震の直上であること，時間 的・空間的に移動することなどから，その発生にはスラ ブからの脱水した流体が関わっていると考えられている [例えば, Katsumata and Kamaya (2003), Miyazawa and Mori (2005)]。 また，低周波微動の一部を構成する 深部低周波地震は, 流体の流れではなくプレートの滑り 運動に伴う現象であることが明らかになってきたが [Shelly et al. (2006), Ide et al. (2007)], 低周波微動のメ カニズムには不明な点が多い.

このような低周波微動が，関東地方・四国地方東部・ 九州地方中南部では観測されていない (Fig. 1 参照). こ の理由として, Seno and Yamasaki (2003) は, これら の地域に沈み込んでいる海洋地殼が通常の玄武岩質の海 洋地殻でなく，含水鉱物をあまり多く含まない花崗岩質 の地殼であるため, 海洋地殼からの脱水が少ないからで あると結論づけた。

彼らは, スラブ地款地震とスラブマントル地震の原因 がスラブ内の含水鉱物の脱水不安定である[例えば, Kirby et al. (1996), Hacker et al. (2003), Yamasaki and Seno (2003)] との仮定のうえで, 上述の低周波微動の起 こっていない地域では海洋地殼からの脱水が少なく， ス ラブ地殼地震は起こっていない（スラブ内地震はすべて スラブマントル地震である）と考えた. さらに，上記の 地域のうち, 九州中南部 $100 \mathrm{~km}$ 以浅以外の場所でこの ことが正しいことを示した。彼らによれば，関東地方に ついては，スラスト地震帯直下の二重面上面の地震の観 測波形の特徵 [堀(1997)］から，スラブ地殼地震は起 こっていないと考えられる. また, 四国東部については, スラブ内地震がマントル内でのみ起こっていることは, 人工地震探査 [Kodaira et al. (2002), 蔵下・他 (2002)] やレシーバー関数解析 [Yamauchi et al. (2003), Shiomi et al. (2004)] から明らかにされている。フィリピン海プ レートの沈み込む他の地域では, 低周波微動が起こって おり [Obara (2002)]，スラブ内地震はほとんどが海洋地 殼内で発生している [Hori et al. (1985), Ohkura (2000)] と考えられるが，関東地方や四国地方東部では対照的に 低周波微動が起こっておらず，スラブ地殼地震が起こっ ていないのである。九州中南部については, $100 \mathrm{~km} よ$ り深い地震については down-dip tension 型といえる地 震が卓越していること［後藤・本田 (2001), 後藤・他 

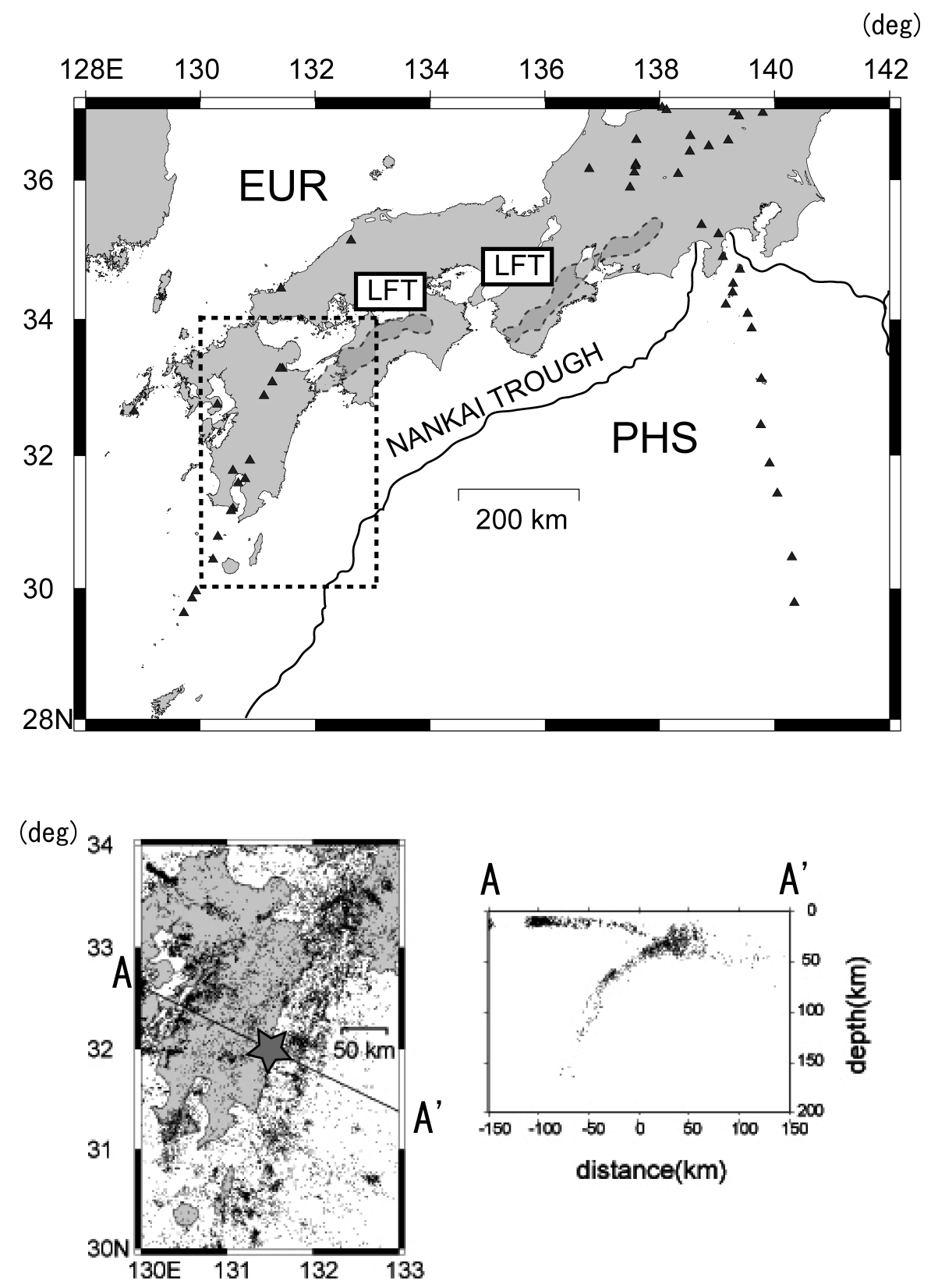

Fig. 1. Top: Tectonic map of southwest Japan. Dashed lines enclose regions of deep low frequency tremor (LFT) determined by Obara (2002). Triangles indicate the active volcanoes.

Bottom left: Epicenter distribution of the earthquakes with a depth $\geq 5 \mathrm{~km}$ as determined by Japan Meteorological Agency (JMA) from January, 2004 to December 2005. The Line A-A' is a projection line of the vertical cross-section and a star indicates the middle point of $\mathrm{A}-\mathrm{A}, 0 \mathrm{~km}$ in the cross section.

Bottom right: Vertical cross-section of the hypocenters. Earthquakes located within $20 \mathrm{~km}$ of the transect are plotted. 
(2001)] から， スラブマントル地震のみが起こっている と考えられるが， $100 \mathrm{~km}$ 以浅の地震がスラブのどこで 起こっているのかはまだよくわかっていない，そこで本 研究では, 九州地方中南部でスラブ地殼地震が起こって いるか否かを調べるために，海洋地殼内を直達波として 伝わる後続波の解析を行い, Double-Difference 法によ る震源再決定を行った。

\section{§2. 後続波の解析}

海洋地殼のような低速層内で地震が起こると，そこを 伝わってきた実体波（Fig. 2(a) の点線，多くの場合直達 波）がその下の高速層内を伝わる実体波（同図の実線， 屈折波）のあとに観測点に到達する。このような地震波 を低速度層が浅くなる方向で観測すると，マントルを 通ってきた小振幅の $\mathrm{P}, \mathrm{S}$ 波の後ろにそれぞれの顕著な 後続相を屯つ波形がえられる。すなわち，このような波 形が海洋地殼の浅くなる方向，つまりプレートの浅くな る方向で観測されれば, その地震は海洋地殼内で起こっ た可能性が高いのである。ただし，このような後続波が 存在するためには, 震源, 大陸地殼之海洋地殼の境界上 の一点, 観測点の三点を通る地震波のパスが必要である

(a)

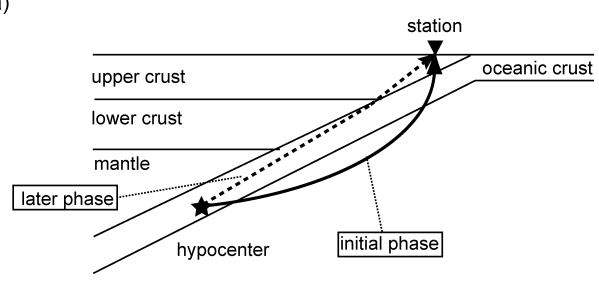

(b)

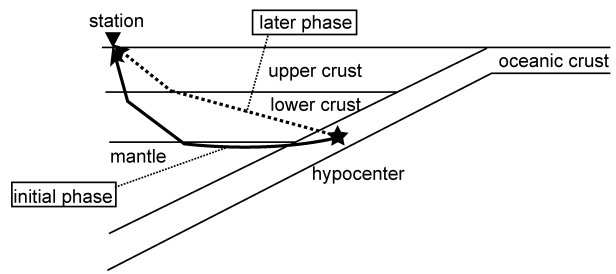

Fig. 2. Possible ray paths for the initial and the later phases projected on the vertical section. Solid and broken lines indicate the ray paths of the initial and the later phases, respectively. (a) The case in which the later phases are observed for paths traveling to the direction where the slab becomes shallower. (b) The case in which the later phases of a shallow earthquake are observed for paths traveling to the direction where the slab becomes deeper.
[Ohkura (2000)]. 以下，このような地震波を単に後続波 と呼ぶ.

今回の研究対象である九州中南部の地震では, プレー トの沈み込む方向は北西であり，後続波が期待できるの は主に中国・四国地方の観測点である．この場合，四国 地方から中国地方にかけての後続波のパスは，Fig. 2(a) のように海洋地殼から陸側下部地殼に入っていくもので ある。ただし，解析においては以下の点に注意する必要 がある。

(1) 深さが $60 \mathrm{~km}$ 程度より深い海洋地殼内で起こった 地震については，海洋地殼が相転移して低速度層ではな くなり，後続波が見られない可能性がある[例えば, Hori et al. (1985)]. つまり，今回の解析では深さが 60 $\mathrm{km}$ を超えるような地震がスラブのよ゙こで起こっている のかは議論できないかもしれない.

(2) 震源が陸側のモホ面よりも浅く，震源と観測点の間 で海洋地殼と大陸地殼が接している場合, スラブが深く なる方向である九州西部の観測点でも Fig. 2(b) のよう なパスの後続波が確認されることがありうる [Ohkura (2000) 参照].

（3）海洋地殼上面で発生するプレート境界地震にも Fig. 2(a)のような後続波が観測される可能性がある。そ こで, 後続波が観測された地震がスラブ内地震かプレー 卜境界地震を判定するためには, 震源メカニズムなどの 情報が必要である。

波形を調べた地震は，後藤・本田 (2001) の附表 1 で 九州中部の, 深さ $30 \mathrm{~km}$ 以上, マグニチュード 3.0 以上 の屯のである。その期間は 1996 年 5 月から 1999 年 10 月, 北緯 30.479 度加ら 32.492 度, 東経 130.215 度加ら 131.927 度であり, 全部で 43 個ある. なお, 今回調べた 地震には深さの下限は設けていない。解析に用いた地震 の震央分布を，波形を調べた観測点とと屯に Fig. 3 に示 す。なお，これらの地震については，後藤・本田 (2001) によってメカニズムが求められている. 波形デー夕は, 全国地震データ流通システム [堀内・他 (1997), 鷹野・ 他 (1997)] で公開されているイベント波形データを用い た。このシステムでは, データ流通ネットワークを通し て全国の 9 大学と気象庁の地震波形デー夕が公開され ている，地震数が 43 個とやや少ないが，上記の条件を 満たし，全国地震デー夕流通システムで中国・四国地方 における観測波形が得られるものすべてについて解析を 行った.

波形を調べる具体的な手順は以下のとおりである

(1) 波形デー夕を，中国・四国地方のものと九州地方の ものに分ける.

（2）それぞれの地域について，波形を震央距離順に並べ 
(deg)

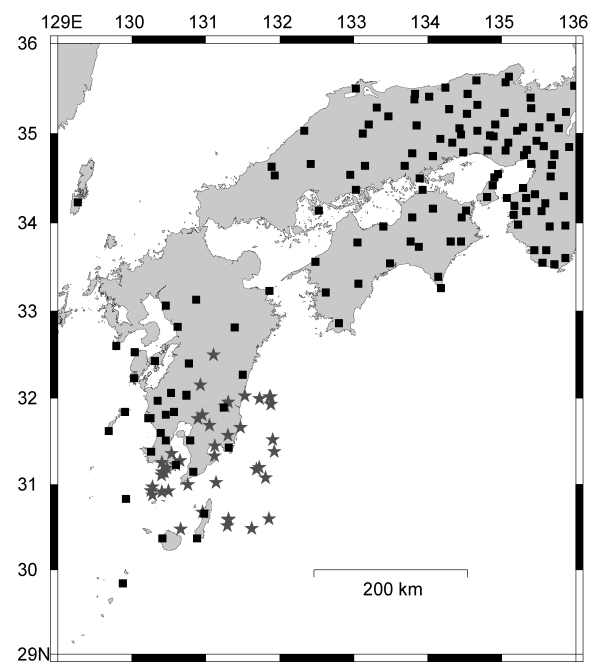

Fig. 3. Location of earthquakes and stations used in the later phase analysis. Stars indicate earthquakes selected from those listed in Table 1 of Goto and Honda (2001), with a magnitude $\geqq 3.0$, a focal depth $\geqq 30.0$ $\mathrm{km}$, and within the period from May, 1996 to December, 1999. Squares indicate seismic stations including the stations of Kagoshima University, Kyushu University, Kochi University, Kyoto University, University of Tokyo and the JMA.

る.

(3) 後続波の有無が調べやすいように, $S / N$ のよい波 形を優先して適度に間引く。

（4）中国・四国地方の観測点の波形について後続波の 有無を判断する。このとき，後続波の見かけ速度が海洋 地殼の地震波速度とほぼ一致し, 九州地方の観測点の波 形に同じような後続波が見られないような場合，この地 震が海洋地款内で発生したものであり, 海洋地壳と大陸 地殻を通ってきた波が後続波として観測されたと考えら れる.

全 43 個の地震の波形を調べた結果, 後続波が見られ た地震は 8 個, 見られなかった地震は 25 個であった。 また，10 個の地震に関しては後続波の有無が判断でき なかった。これは, 中国・四国のイベント波形データが ない, むしくは波形のノイズが大きく $(S / N$ が悪く $)$ 判 断が難しかったためである.

後続波の見られた地震波形の例を Fig. 4(a) に示す. この地震を含め, $\mathrm{P}$ 波の見かけ速度が約 $8 \mathrm{~km} / \mathrm{sec}$ であ るのに対して, 確認された後続波の見かけ速度は 6.5$7.0 \mathrm{~km} / \mathrm{sec}$ 程度であり, 後続波に関する過去の研究 [例
えば, Hori (1990), Ohkura (2000)] に調和的である。ま た，同じ地震でもスラブの深くなる方向に当たる九州地 方の観測点では後続波が見られない (Fig. 4(b) 参照).

Fig. 4(a) に示したように後続波は P 波だけでなく $\mathrm{S}$ 波 にあ見られる. S 波の速度がおよそ $4.5 \mathrm{~km} / \mathrm{sec}$ である に対し, S 波の後続波の速度は 3.6-4.0 km/sec である. $\mathrm{SP}, \mathrm{PS}$ 変換波などではこのような後続波を説明できな いこと，さらに，スラブの浅くなる方向でのみ見られる ことから，この後続波がスラブの海洋地殼をほぼ直達波 として伝わってきた可能性が高い. したがって，中国・ 四国地方でのみ後続波の見られた 8 個の地震はスラブ 地殼地震, あしくはプレート境界地震であるといえる. 一方, 中国・四国地方の観測点で屯後続波の見られな かった地震波形の例を Fig. 5 に示す.

次に, 後続波の見られた 8 個の地震がスラブ地殼地震 から゙うかを決めるため, 後藤・本田 (2001) によって決 められたメカニズムを調べた. Fig. 6 は後続波の見られ た 8 個すべての地震 (a) と, 見られなかった地震のうち の一部のメカニズム解 (b) である. まず, 後続波の有無 とメカニズム解との間に系統的な関係はない。ただし， 後続波の見られた地震については, 正断層型の地震が多 い. 後続波の見られた地震のうち, プレート境界地震の 可能性のある地震は, 低角逆断層型のメカニズム解を示 す丸で囲んだ一つである. 他の 7 個の地震はその可能性 は低く，スラブ地殼地震であると考えられる.

\section{§ 3. Double-Diff erence 法による震源再決定}

前章のようにして後続波の有無が判断できたので，そ れらの地震が地震面のどこに位置しているのかを検討す る. 気象庁の一元化震源 (Fig. 1) では, 特に日向灘など 海域で地震発生層が厚く $(20-30 \mathrm{~km})$ なっており, さら に, 地震面から外れた地震も多数ある。したがって, 後 続波を解析した地震の相対的位置を知るためには精度が 足りない可能性がある。そこで, より相対精度のよい震 源を得るために, Double-Difference（以下 DD とする） 法による震源再決定を行った.

DD 震源決定法は Waldhauser and Ellsworth (2000) によって開発された震源決定法である。波線がほぼ共通 な地震のペアの走時差の, 観測值と計算值の差が最小に なるよう震源を決めることからこの名がついている。こ れにより, 速度構造などの影響が小さく, 相対位置の精 度が高い震源が得られる. 用いたデー夕は, 次の条件を 満たす地震の気象庁の読み取り值データである.

(1) 期間：1996 年 1 月から 2001 年 12 月

(2) 震源：北緯 30-33 度, 東経 130-133 度, 深さ 25 $\mathrm{km}$ 以上 
(a)
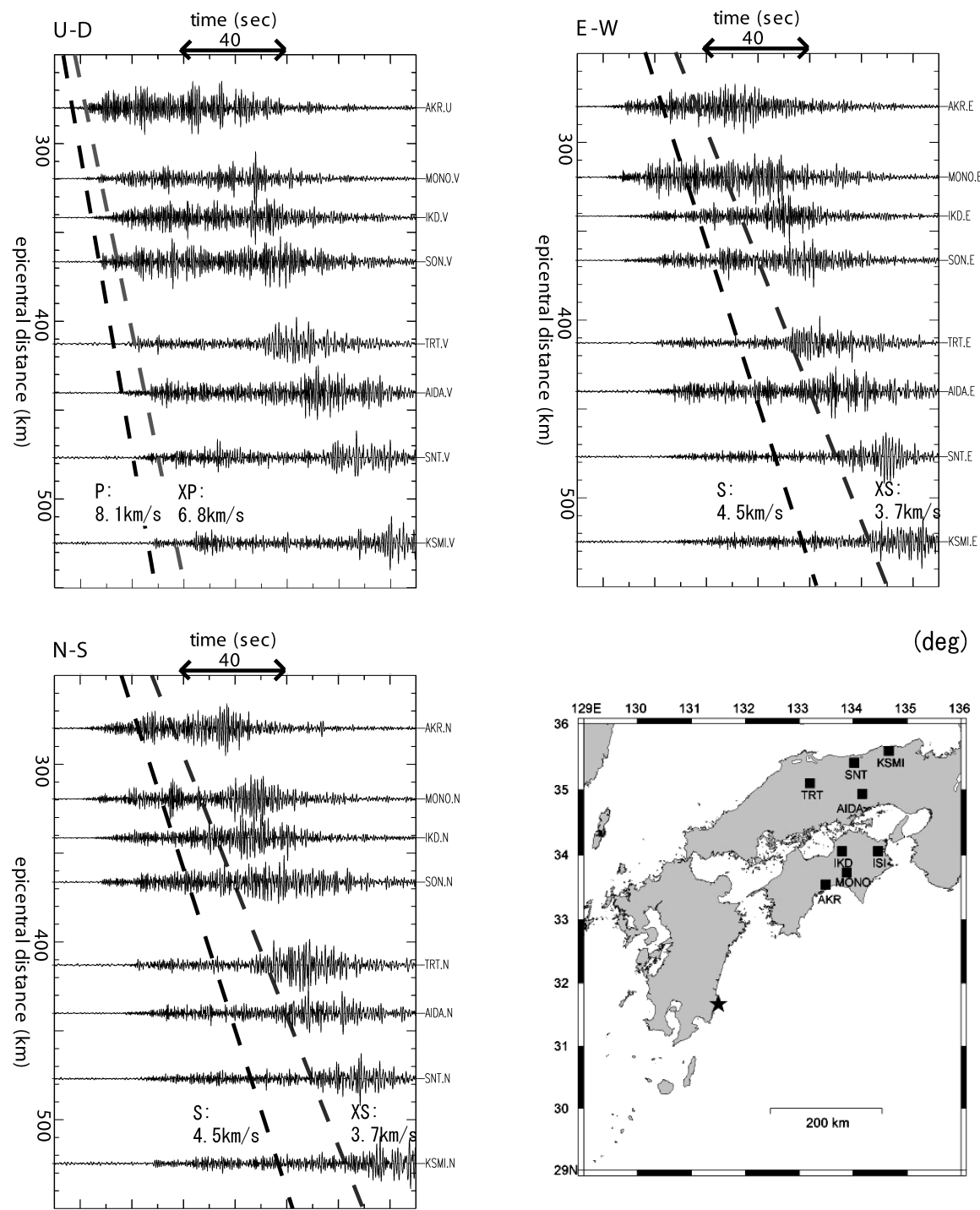

(deg)

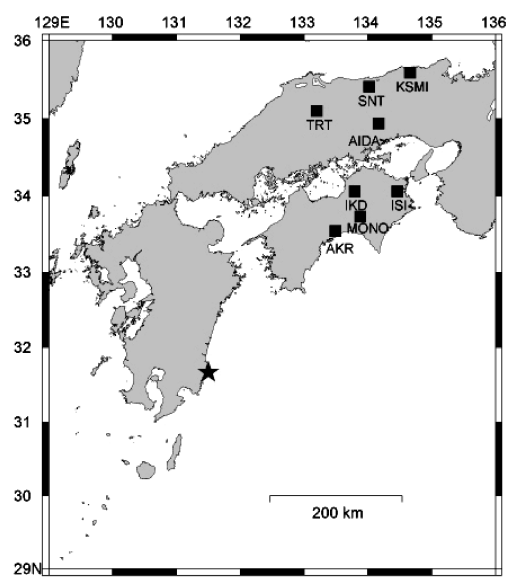

Fig. 4. Examples of waveforms of an event on April 18, 1999 with a depth of $38.3 \mathrm{~km}$ and a magnitude of 4.1. (a) The waveforms observed at the stations in Chugoku-Shikoku district associated with the later phases. Top left, top right and bottom left: waveforms of up-down, east-west and north-south components, respectively. They are assembled in order of epicentral distance. Bottom right: location of the earthquake (star) and stations (squares). (b) The waveforms observed in Kyushu district without distinct later arrivals.

(3) $\mathrm{P}$ 波と $\mathrm{S}$ 波の読み取り值があわせて 8 個以上

なお，気象庁による一元化デー夕処理が 1997 年 10 月 から開始されているが，後続波の解析に用いたデータの 期間にあわせるため，1996 年 1 月からのデー夕を用い た. 解析に用いた観測点之震源の分布を Fig. 7 に示す. 上のような条件で選んだ地震の数は 12,138 個である. 次にこれらの地震を一定距離以内にあるもの同士をぺア
にして相対走時を計算し， DD 震源決定プログラムへの 入力とする. 本研究では, 最大の地震間距離は $20 \mathrm{~km}$ と し, 上野・他 (2002)によるJMA2001 を速度構造とし て用いて震源再決定を行った。

震源再決定の結果を Fig. 8 に示す. 図中の点線は各断 面図の投影面を表しており，その走向は稍深発地震の等 深線にほぼ直交している。なお，投影面から $20 \mathrm{~km}$ 以内 
(b)
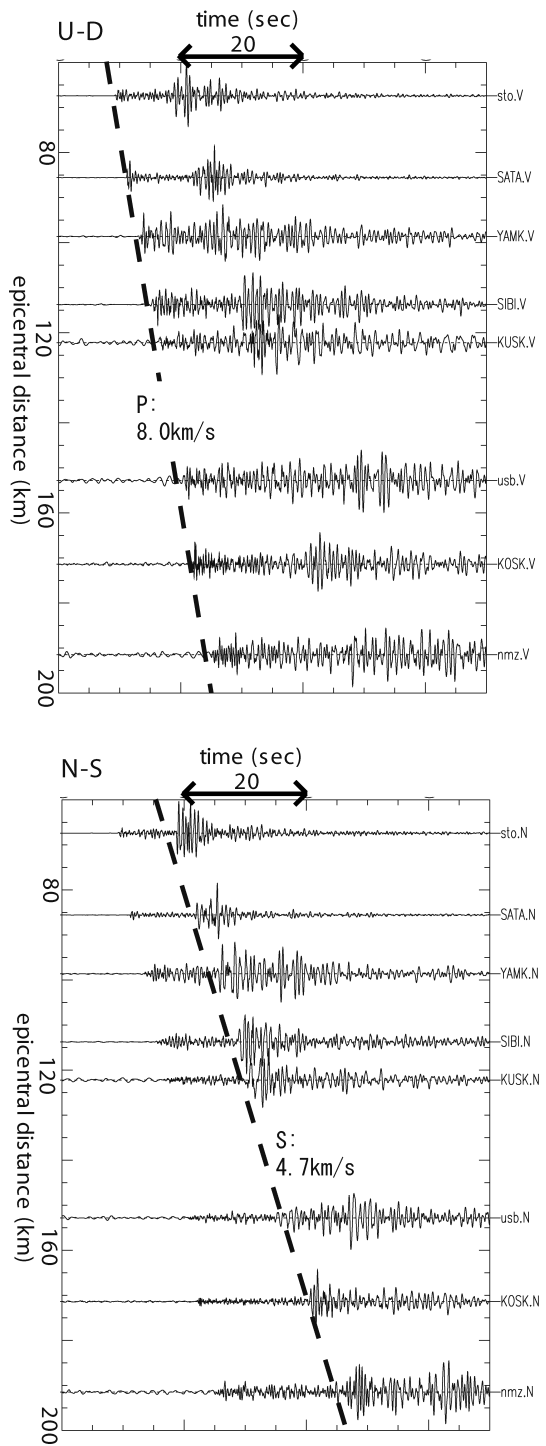

の地震が各断面図に描かれている。 また，断面図の原点 (+) は $65 \mathrm{~km}$ の等深線の位置にほぼ等しい，後続波の 見られなかった地震は○，判断のできなかった地震は で示している. また, 後続波の見られた地震のうち, メ カニズム解からスラブ地殻地震であるといえる地震 $(6$ 個) は $\triangle$, プレート境界地震である可能性がある地震 (1 個）は々で示してある.なお，スラブ地殼地震の可能性 があるあう一つの地震は，読み取り值が少なかったため 再決定されなかった。再決定された震源のうち，後続波 の観測された地震はすべて地震発生層の上層部に位置し ている（断面 4, 5, 6）こと，後続波が観測されていない

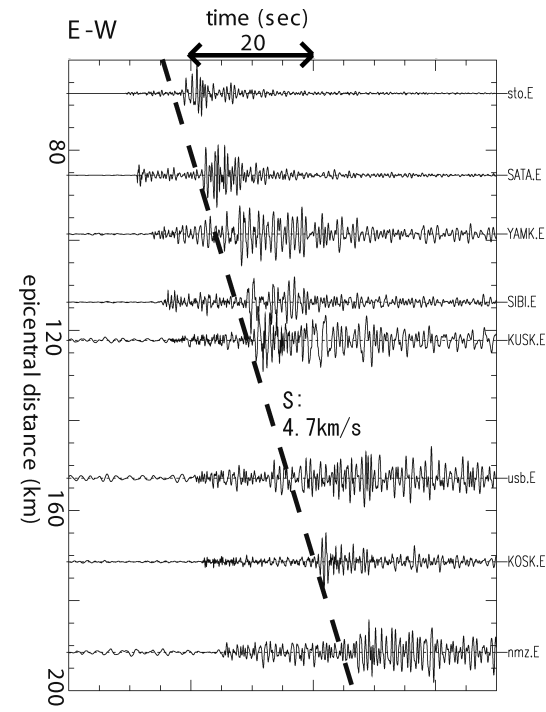

(deg)

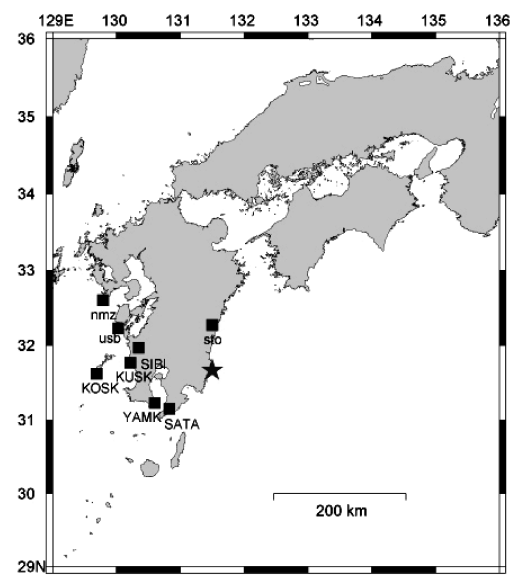

地震は下層部に位置していることがわかる（断面 $1,2,3$, $4,6)$.

なお，震源再決定後の水平方向の標準誤差の RMS は $0.52 \mathrm{~km}$, 鉛直方向のそれは $0.49 \mathrm{~km}$ であった. 一元化 震源の水平位置, 深さの標準誤差の RMS はそれぞれ $1.58 \mathrm{~km}, 2.10 \mathrm{~km}$ であることから，DD 法により精度よ く再決定されていることがわかる. また, 断面 3 や断面 4 の $\mathrm{X}=50$ から $100 \mathrm{~km}$ の地震発生域の厚さは, 再決 定前が約 $40 \mathrm{~km}$ であったあのが $20 \mathrm{~km}$ 程度に薄くなっ た. そして, 深さ $150 \mathrm{~km}$ の地震発生層の厚さむ一元化 震源の $20 \mathrm{~km}$ から $10 \mathrm{~km}$ 程度に減少にしている．以上 

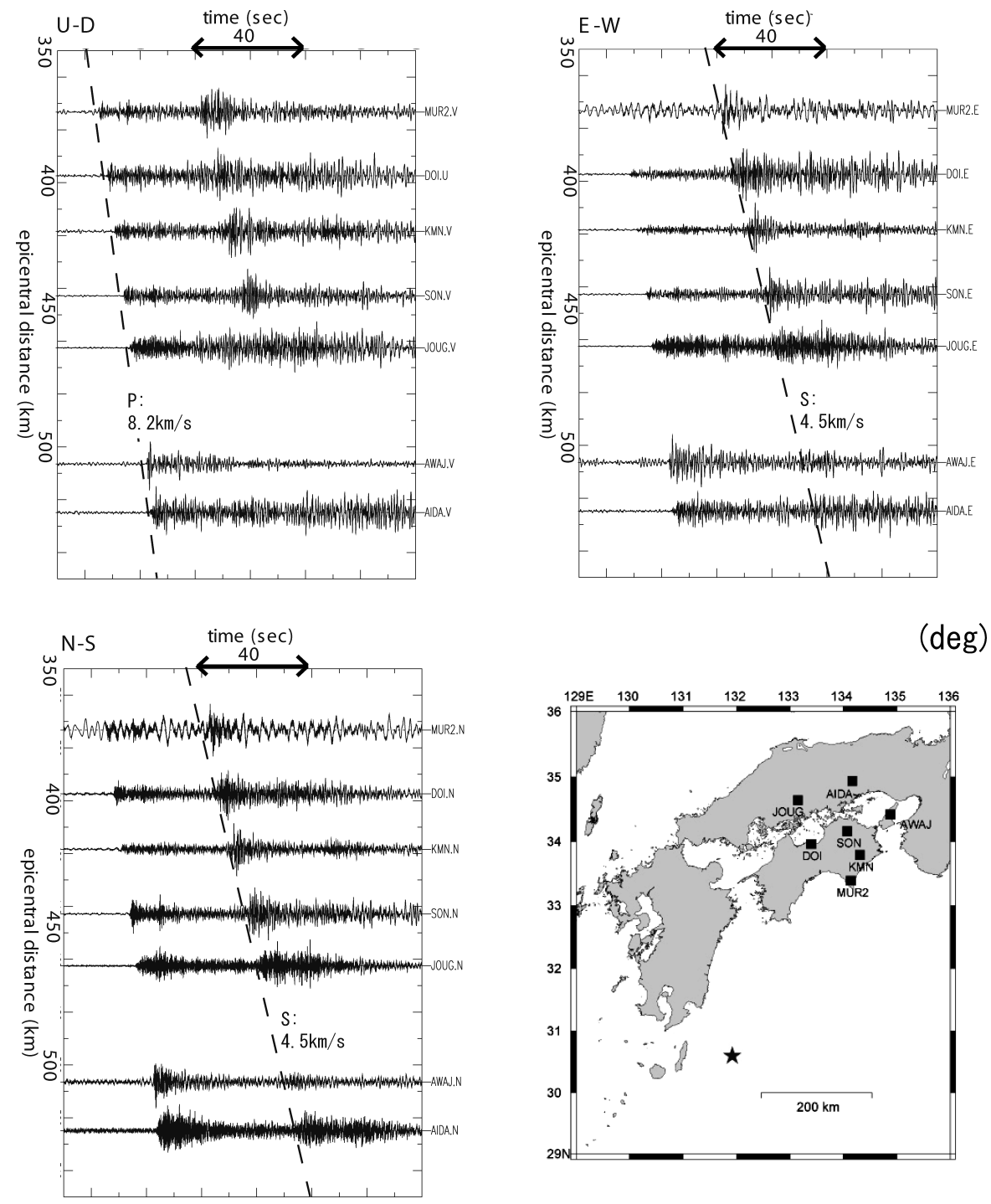

(deg)

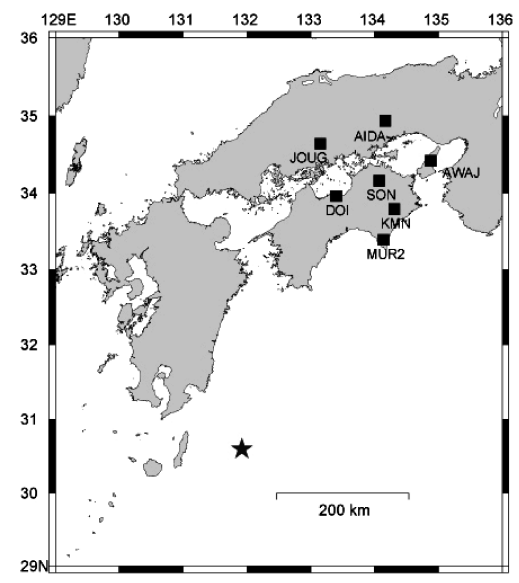

Fig. 5. An example of waveforms observed at the stations in Chugoku-Shikoku district without distinct later arrivals from an event on February 18, 1999, with a depth of $49.3 \mathrm{~km}$ and a magnitude of 5.0 .

のことから，再決定後の精度が全体的に向上しているこ とがわかる。

角田・他 (1995) には，本研究領域の断面 5 と断面 4 間 (加久藤カルデラ直下域), 断面 4 と断面 3 間 (姶良力 ルデラ直下域)，そして断面 3 と断面 2 間（阿多カルデ ラ直下域）にフィリピン海プレートの断裂が存在するこ とが示されている. 具体的には, 断面 5 と断面 4 の間に 地震面の左横ずれの不連続があり，そのずれの量は，50 $\mathrm{km}$ から $70 \mathrm{~km}$ の深さで最大 $10 \mathrm{~km}$ 程度とされてい る. また，断面 4 と断面 3 間および断面 3 と断面 2 間に あ地震面の左横ずれの不連続があり, そのずれの量は,
$70 \mathrm{~km}$ から $100 \mathrm{~km}$ の深さで最大值 $10 \mathrm{~km}$ をとる.こ れらのずれは再決定後の震源分布にも認められ, Fig. 8 の断面 5 の深さ $50 \mathrm{~km}$ から $70 \mathrm{~km}$ の地震面が断面 4 のそれと比べ $10 \mathrm{~km}$ 程度左へずれていることがわかる. また， 断面 3 と断面 2 , 断面 4 と断面 3 では $70 \mathrm{~km}$ と $120 \mathrm{~km}$ の間に同様のずれがあり，これらは角田・他 (1995) の結果と調和的である.

\section{§4. 議論}

4.1 スラブ内地震はどこで起こっているか

後続波の見られる地震の分布には, 研究領域の南北に 
(a)
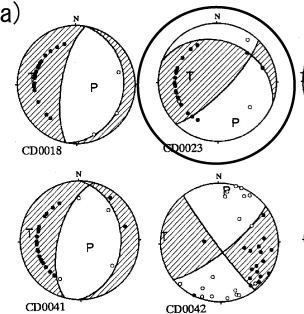

(b)
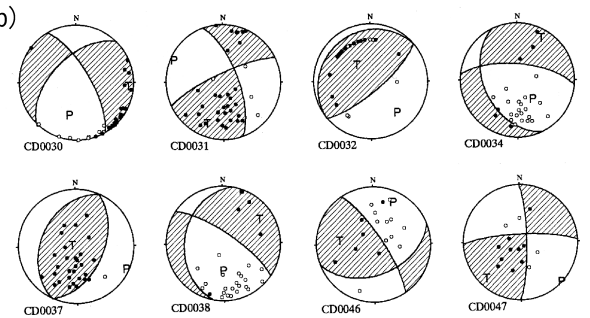

Fig. 6. (a) Focal mechanisms of all the earthquake associated with the later phase taken from Goto and Honda (2001). The circled focal mechanism shows a low-angle thrust type, so this earthquake would be an interplate earthquake. The others are considered to occur within the Philippine Sea Slab.

(b) Focal mechanisms of several earthquakes associated with no later phase (taken from Goto and Honda (2001)).

おいて明膫な差が認められる。すなおち，後続波の見ら れた地震は, 研究領域の北側 (Fig. 8 の断面 4-6) にの み存在し, 南側 (同じく, 断面 1-3) には存在しない, 後 続波の有無の分布が変わる境界である Fig. 8 の断面 3 と断面 4 の間には, 過去の研究でスラブの断裂やブロッ ク構造境界のひとつと指摘された境界が存在している.

以下, 研究領域の南側 (以下, 領域 I と呼ぶ）と北側（以 下, 領域 II と呼ぶ）について，スラブ内地震がどこで起 こっているのかを考える.

南側の領域 Iでは, 前述の通り, 後続波の見られた地 震が存在しない．この原因として以下のようなことが考 えられる。

(1) 領域内でスラブ地殼地震は発生しているものの後 続波の解析をした地震にスラブ地殼地震がなかった

(2) 領域内ではスラブ地殼地震がまったく発生してい ない

(3) 実際にはスラブ地喨地震が起こっているが, スラブ の断裂により, 後続波のパスが存在しえない.

まず，(3) のスラブ断裂について考察する. 前述したよ うに, 断面 5 と断面 4 の間には地震面のずれが存在して いる。しかし，実際にスラブが断裂しているとしても，

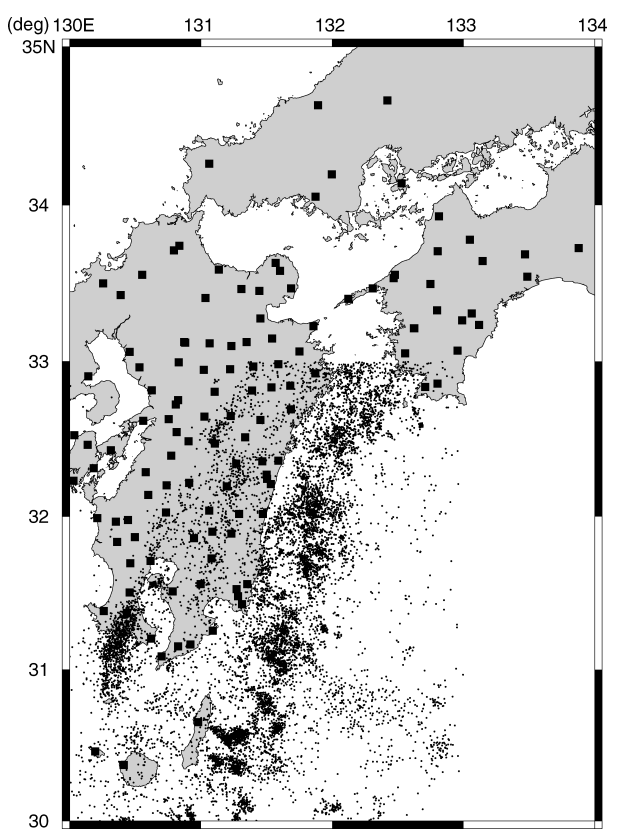

Fig. 7. JMA locations of earthquakes and stations used in double-difference hypocenter determination. Squares indicate the stations.

50-60 km の深さにおいて, 最大でも $10 \mathrm{~km}$ 程度の左 横ずれであり, 海洋地款の厚さと沈み込み角度を考慮す ると, $50 \mathrm{~km}$ 以浅では海洋地殼が完全には不連続になら ない. 断面 4 に後続波か観測された地震が存在すること は, この地震より浅部では断面 4 と断面 5 の間に海洋地 殼の不連続がないことを示している. また，断面 4 と断 面 3 㧍よび断面 3 と断面 2 間の地震面の左横ずれの量 あ $60 \mathrm{~km}$ より浅部では $10 \mathrm{~km}$ 以下であることから, 領 域 Iでは, $60 \mathrm{~km}$ より浅部で, 海洋地殼が不連続になっ ている可能性は低く, この領域の海洋地殼内で地震が発 生すれば，後続波が観測されるはずである。すすおわ 領域 Iに後続波が観測されない地震があるということ は, この領域ではスラブマントルの中で地震が発生して いることを意味している.

一方 (2) の場合では, スラブ内地震の発生様式が領域 I と II で変わっていることになり, その境界が何らかの 物理状態の違いを反映したあのである可能性むある。 ま た, 領域 Iでは地震面の上面はスラブの上面と一致しな いことになるので，この境界を境に地震面の上面がずれ ていることが予想される。しかし，断面 3 と断面 4 の $60 \mathrm{~km}$ 以浅の地震面にはずれが見いだせない. ただし, 領域 I から領域 II にかけて徐々に震源の位置がマント ルから地款へと変わっているとすると, ずれは見えない 

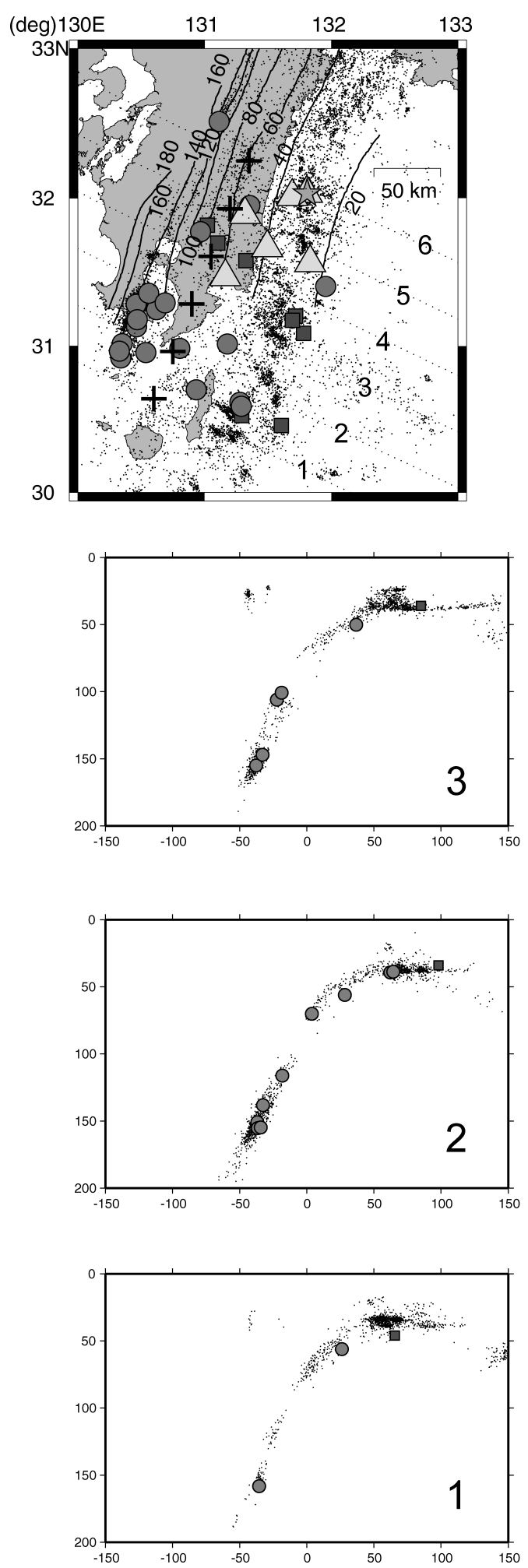

Fig. 8. Hypocenters for Fig. 7 relocated by hypoDD. Triangles and a star indicate the earthquakes with the later phases and circles are the earthquakes with no later phase. The star indicates the low-angle thrust type earthquake. Square symbols indicate earthquakes for which it is not clear whether they are associated with the later phases or not. Solid lines are the isobaths of earthquakes determined by Uehira et al. (2001). Broken lines 1-6 are the projection lines of each vertical cross-section. Pluses indicate $0 \mathrm{~km}$ in the cross sections. Earthquakes located within $20 \mathrm{~km}$ of the transect are plotted.
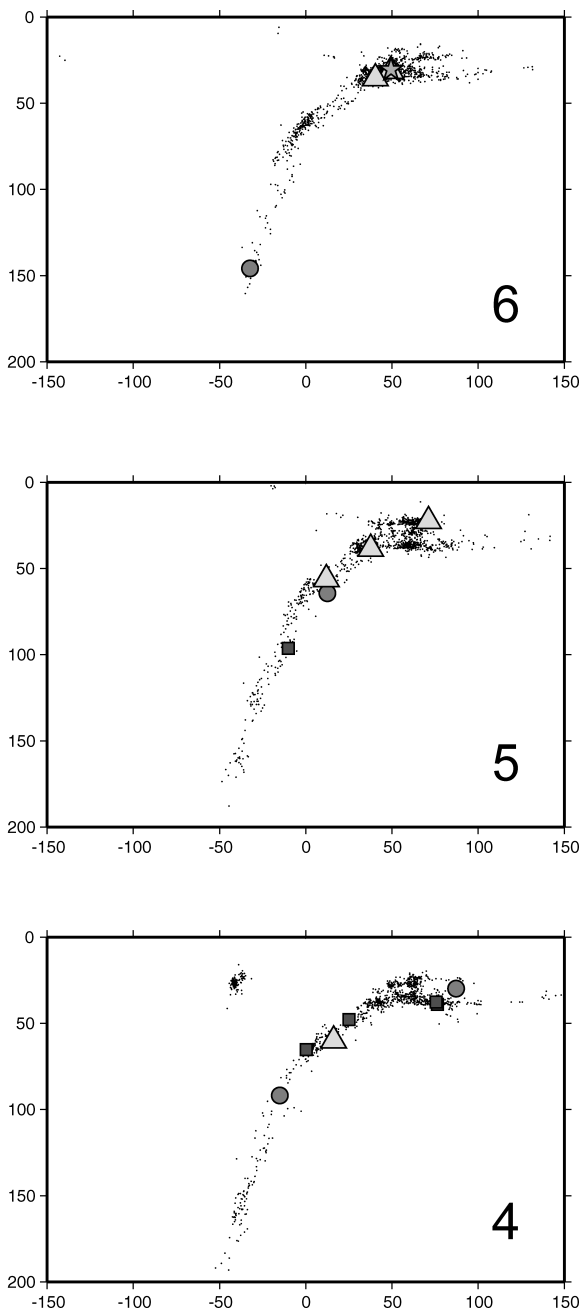
可能性がある. また, 断面 3 や断面 2 では, 後続波の見 られなかった地震の上にも多数の地震が分布しており, それらが海洋地殼で発生していること, すなわち(1)の 可能性は否定できない. しかし, 後続波の見られない地 震が存在しているので, 領域 I ではスラブマントル内で 地震が発生していることは確実である.

本研究では領域 I においてスラブ地殼地震が発生して いるか否かははっきりとはわからなかった。これを明ら かにするためには, 今後海底地震観測に基づく精度の高 い震源決定をし，トモグラフィー，レシーバー関数解析 など他の方法によって決めたスラブ上面と比較をする必 要がある.

一方, 北側の領域 II では後続波が認められ, 低角逆断 層型のメカニズムを示さない地震が存在していることか ら，スラブ地殼地震が起こっていることがわかる．低角 逆断層型のメカニズムを示す地震 (印) あ地震面の内 部に存在しており, その直下にスラブ地殼地震が存在し ている. 震源の深さの精度が不十分である可能性あある が，この地震もスラブ地殼地震である可能性がある。い ずれにしても, この領域でスラブ地殼地震が発生してい ることは明らかである。

後続波の見られない地震については, 断面 5 に深さ $66.2 \mathrm{~km}$ (再決定後)のあのが存在する. しかしそれ以深 で後続波の見られる地震が存在しないことから，この地 震がスラブマントル地震か相転移後の海洋地殻で起きた スラブ地殼地震であるかは判断しがたい. また，断面 4 には, 海域に後続波の見られない地震が存在している. この地震が海洋地殼で発生しているとすると, スラブ等 深線に平行に海洋地殼内を伝わる波が四国地方で後続波 として観測されるはずであり, この地震はスラブマント ル地震である可能性が高い. 領域 II の $60 \mathrm{~km}$ 以浅で, すなわち海洋地殼が相転移していない深さで起こった地 震のうち後続波の見られなかった地震はこの地震のみで ある. しかし, この地震の直下にも多数の地震が再決定 されていることから，この領域ではその他にあスラブマ ントル地震が発生していると考えられる. したがって, 北部では地款, マントルの両方で地震が起こっているこ とになる、今後, これらの地震がはっきりとした二重面 を形成しているか, 地殼からマントルにかけて連続的に 発生しているかどうかを詳細に調べることが，スラブの 温度・圧力状態を推定するうえで重要であろう.

本研究では, 領域 II ではスラブ地壳地震が, 領域 I と II の両方でスラブマントル地震が発生していることがわ かった. スラブ内地震が含水鉱物の脱水不安定で起こる とすると, 領域 I では海洋マントルが, 領域 II では海洋 地款と海洋マントルの両方が含水化している必要があ
る. 海洋地款については, 中央海嶺付近での熱水循環に よって含水化した可能性が高い. また, 海洋マントルに ついては, 九州-パラオ海嶺が伊豆一小笠原弧と合体して いたときに蛇紋岩化した可能性がある（背弧火成活動に よる蛇紋岩化, Seno et al. (2001) 参照).

近年, 九州地方においても観測網が整ってきたことに より多数の地震や観測点を用いて速度構造の推定が行わ れている. Wang and Zhao (2006)では, 6,285 個の地 震と 185 の観測点を用いて九州全域下の地殼・上部マ ントル速度構造が推定されている. 彼らの結果による と, $60 \mathrm{~km}$ 以浅の地震の多くは高速度領域に位置してい る. また, 彼らの結果でも地震面の厚さは一般的な海洋 地殼の厚さを超えており, スラブマントル地震が起こっ ている可能性が高い.ただし彼らの解析において，この 深さでの鉛直方向のグリッド間隔は $10 \mathrm{~km}$ であり, ま た, 海洋地殼と思われる低速度層は検出されていない. スラブ内地震がどこで起こっているかをトモグラフィー の手法を用いて知るためには，鉛直方向に細かなグリッ ドに区切り計算を行う必要があると思われる。

\section{2 深部低周波微動之の関係}

本研究の後続波解析の結果から, 九州中南部でも北側 の領域 II ではスラブ地殼地震が発生していることがわ かった. Seno and Yamasaki (2003) は, 深部低周波微 動の発生していない地域である九州中南部では, スラブ 内地震は地殼内ではほとんど起こらないと予想したが, 少なくとも九州中部に抢ける本研究の結果は彼らの予想 に反するものとなった. その理由として, 次のようなこ とが考えられる。

(1) 実際には低周波微動が起こっているのに, 九州の東 側 (太平洋底) の観測点の不足などで観測されていない. (2) スラブ地殻地震は九州中南部全域の現象ではなく, 限られた地域の屯のである. むしくは, 海洋地款内地震 の割合はごく小さいあのである.

(3) 四国東部などとは違って, スラブ地殼地震が発生し ているのに, 低周波微動は起こっていない.

(1)に関して, 四国や東海において低周波微動はスラ ブ深度が抢拉む称 $30 \mathrm{~km}$ の位置に分布しているが，九 州中南部でこの深さに該当するスラブ領域の半分程度は 海域下である. しかし, 豊後水道など海域であ低周波微 動の観測はされている. 近年, 九州地方の地震検知能力 が向上したことも考えると, やはり九州地方中南部では 低周波微動は発生していない可能性が高い.

(2) に関しては, 本研究で後続波の見られた地震は 8 個であり，そのうちメカニズム解からスラブ地殼地震で あるといえる地震は 7 個である.これは全体の地震数か ら見ればごくわずかである。しかしながら，それらの地 
震は厚さ $20 \mathrm{~km}$ 程度の地震面から孤立した地震でない ことから, この領域では相当数のスラブ地殼地震が起 こっていると考えられる.

一方, (3) に関して, 海洋地款の脱水による流体の存在 だけが低周波微動の発生条件であるのかどうかあ考えな くてはならない. 鎌谷・勝間田 (2004) は東海から豊後 水道にかけての地域で低周波微動が発生する条件につい て, 深度 $30 \mathrm{~km}$ 付近でスラブ上面とマントルウェッジ が接していないことを挙げた。彼らによると，フィリピ ン海プレートが沈み込み深さ $30 \mathrm{~km}$ 付近に達したとこ ろで海洋地殼の脱水により水が発生する. このとき, ス ラブ上部にマントルウェッジがない（すなわち，大陸下 部地殼と接している）と低周波微動が発生しうるが， マ ントルウェッジが存在すると水は蛇紋岩に固定されて流 動できず，低周波微動は発生しないのである，彼らは， 低周波微動帯の北縁はスラブとマントルウェッジが接触 し始めた位置にあたるとしている. また, 四国東部で微 動帯が途切れていることに関しては, 同様の理由かもし くは紀伊半島下で脱水を終えたスラブが平行移動してい るためであるとしている. 九州地方に関しては, 日向灘 においてマントルウェッジとスラブが接していない場 合, 微動が発生している可能性があるとしている. 本研 究においては, Fig. 4 の地震などのように, 中国・四国 地方の観測点で後続波が観測された深さ $30 \mathrm{~km}$ 程度の 地震でも, 九州地方の観測点で後続波は見られなかっ た.これは,これらの地震発生域においてスラブが大陸 地款に接していない, すなわちマントルウェッジに接し ていることを示唆している [Ohkura (2000) 参照]. ただ し, 鎌谷・勝間田 (2004) では九州地方のフィリピン海 スラブ近傍の温度・圧力条件は検討されていない. した がって，この領域においてスラブの脱水がどの深さ，部 分で起こりうるかを知るために, スラブ, マントル ウェッジの温度構造の推定が必要であろう。

また, 大陸地殼, 海洋地殼, マントルウェッジがどの ように接しているかを知るためには, 海底地震観測, 詳 細なトモグラフィー, あるいはレシーバー関数解析など が必要である。

\section{§5. ま と め}

本研究では, 九州地方中南部においてスラブ内地震が ごこで起こっているのかを解析した，海洋地殼を伝わっ てきた後続波の有無を調べ, さらに, それらの地震が地 震面のどこに位置しているのかを高い相対精度で知るた めに Double-Difference 法による震源再決定を行った. その結果, 研究領域の北側ではスラブ地殼地震とスラブ マントル地震の両方が, また, 南側ではスラブマントル
地震が起こっていることが明らかになった。しかし，南 側でスラブ地殼地震が起こっているか否かはわからな かった.

本研究の結果, 九州地方中部では, 低周波微動が発生 していない領域であ, スラブ地款地震が発生しているこ とが明らかになった。これは Seno and Yamasaki (2003) のモデルでは説明できないことであり, 九州中部 で低周波微動が発生しないことを説明することのできる 新たなモデルの構築が今後必要である.

\section{謝辞}

後続波の解析に用いた波形デー夕は, 気象庁・防災科 学技術研究所 Hi-net - 鹿児島大学・九州大学・京都大 学・高知大学・東京大学のものを使わせていただきまし た. また, 震源再決定には, Waldhauser and Ellsworth (2000)による Double-Difference 震源決定プログラム を使わせていただきました．また気象庁の一元化処理に よる読み取り值データと震源データを使わせていただき ました。図の多くは, GMT (Generic Mapping Tools [Wessel and Smith (1995)]) により作成させていただき ました。 波形データの取得には京都大学の大見士朗氏, 鹿児島大学の八木原 寛氏, 震源再決定には京都大学の 久家慶子氏にたいへんお世話になりました．2名の匿名 査読者および編集員の勝間田明男氏には本稿を改善する うえで有益なご意見をいただきました。 ここに記して感 謝します。

\section{文献}

後藤和彦・本田貴子，2001, 九州中南部に発生した稍深 発地震の発震機構, 南九州下の稍深発地震とサイスモ テクトニクス 平成 $11 \cdot 12$ 年度科学研究費補助金基盤 研究 $\mathrm{C}(2)$ 研究成果報告書, 51-109.

後藤和彦・本田貴子・八木原寛・角田寿喜・清水 洋, 2001, 南九州に打ける稍深発地震面の形状と発震機 構, 月刊地球, 23, 664-668.

Hacker, B. R., S. M. Peacock, G. A. Abers, and S. D. Holloway, 2003, Subduction factory-2. Are intermediate-depth earthquakes in subducting slabs linked to metamorphic dehydration reactions?, J. Geophys. Res., 108(B1), doi: 10.1029/2001JB 001129.

Hori, S., 1990, Seismic waves guided by untransformed oceanic crust subducting into the mantle: the case of the Kanto district, central Japan, Tectonophysics, 176, 355-376.

堀 貞喜, 1997 , 関東地方下のフィリピン海プレート内 地震の発生機構, 地震 2, 50, 203-213.

Hori, S., 2006, Seisimc activity associated with the subducting motion of the Philippine Sea plate beneath the Kanto district, Japan, Tectonophysics, 
417, 85-100.

Hori, S., H. Inoue, Y. Fukao, and M. Ukawa, 1985, Seismic detection of the untransformed 'basaltic' oceanic crust subducting into the mantle, Geophys. J. Roy. Astr. Soc., 83, 169-197.

堀内茂木 ・ 鷹野 澄・ 卜部 卓・平田 直・高波鉄夫 小菅正裕・松沢 暢・山崎文人・片尾浩・木村昌 三・清水 洋・後藤和彦・小原一成・宇平幸一, 1997, 全国地震データ流通システム (1)一地震波形 データベースとその利用法一, 地球惑星科学関連学会 合同大会予稿集, 67 .

Ide, S., D. R. Shelly, and G. C. Beroza, 2007, Mechanism of deep low frequency earthquakes: Further evidencethat deep non-volcanic tremor is generated by shear slip on the plate interface, Geophys. Res. Lett., 34, doi: 10. 1029/2006GL 028890.

石川有三, 2001, フィリピン海スラブの形状, 地学雑誌, 110(4), 592-601.

石原和彦・吉田明夫, 1992 , 九州下フィリピン海スラブ の形状と地震活動, 地震 2, 45, 45-51.

鎌谷紀子・勝間田明男, 2004, 火山から離れた地域で発 生している深部低周波微動・地震一その分布と発生原 因一, 地震 $2,57,11-28$.

角田寿喜・宮町宏樹 - 高木章雄, 1991, 九州-琉球弧北 部域の稍深発地震, 地震 $2,44,63-74$.

角田寿喜 - 後藤和彦 - 宮町宏樹 - 平野舟一郎 - 石原和 彦，1995, 地震活動からみた九州南部一南西諸島域の テクトニクス，月刊地球， 17, 414-417.

Katsumata, A. and N. Kamaya, 2003, Low-frequency continuous tremor around the Moho discontinuity away from volcanoes in the southwest Japan, Geophys. Res. Lett., 30, doi: 10.1029/2002GL 015981.

Kirby, S., E. R. Engdhal, and R. Denlinger, 1996, Intermediate-depth intraslab earthquakes and arc volcanisms as physical expressions of crustal and uppermost mantle metamorphism in subducting slabs (Over view), in "Subduction Top to Bottom," ed. by G. E. Bebout, D. W. Scholl, S. H. Kirby, and J. P. Platt, Geophys. Monoger 96, AGU, Washington, D.C., 195-214.

Kodaira, S., E. Kurashimo, J.-O. Park, N. Takahashi, A. Nakanishi, S. Miura, T. Iwasaki, N. Hirata, K. Ito, and Y. Kaneda, 2002, Structural factors controlling the rupture process of a megathrust earthquake at the Nankai trough seismogenic zone, Geophys. J. Int., 149, 815-835.

蔵下英司・徳永雅子・平田 直・岩崎貴哉・小平秀一・ 金田義行・伊藤 潔・西田良平・木村昌三・井川 猛, 2002, 四国西部地域における地殻及び最上部マン トルの地震波速度構造と沈み込むフィリピン海プレー 卜の形状, 地震 2, 54, 489-505.

Miyazawa, M. and J. Mori, 2005, Detection of triggered deep low-frequency events from the 2003 Tokachi-oki earthquake, Geophys. Res. Lett., 32, 307, doi: 10.1029/2005GL022539.
三好崇之・石橋克彦，2004, 震源分布からみた伊勢湾か ら四国西部にかけてのフィリピン海スラブの形状, 地 震 $2,57,139-152$.

長宗留男・田代秀樹, 1989, 九州下における和達一ベニ オフゾーンの形状, 地震 $2,42,13-19$.

Obara, K., 2002, Nonvolcanic deep tremor associated with subduction in southwest Japan, Science, 296, 1679-1681.

Ohkura, T., 2000, Structure of the upper part of the Philippine Sea plate estimated by later phases of upper mantle earthquakes in and around Shikoku, Japan, Tectonophysics, 321, 17-36.

Seno, T. and T. Yamasaki, 2003, Low-frequency tremors, intraslab and interpolate earthquakes in Southwest Japan-from a viewpoint of slab dehydration-, Geophys. Res. Lett., 30, 22, doi: 10.1029/2003GL018349.

Seno, T., D. Zhao, Y. Kobayashi, and M. Nakamura, 2001, Dehydration of serpentinized slab mantle: Seismic evidence from southwest Japan, Earth Planets Space, 53, 861-871.

Shelly, D. R., G. C. Beroza, S. Ide, and S. Nakamula 2006, Low-frequency earthquakes in Shikoku, Japan, and their relationship to episodic tremor and slip, Nature, 442, 188-191.

Shiomi, K., H. Sato, K. Obara, and M. Ohtake, 2004, Configuration of subducting Philippine Sea plate beneath southwest Japan revealed from receiver function analysis based on the multivariate autoregressive model, J. Geophys. Res., 109, B04308, doi: 10.1029/2003JB002774.

鷹野 澄・山中佳子・卜部 卓・趙悦・酒井慎一・ 堀内茂木 - 松沢暢 - 一柳昌義 - 渡辺和俊 - 山崎文人 大見士朗・村村昌三・馬越孝道・後藤和彦・小原一 成・宇平幸一，1997, 全国地震デー夕流通システム $(2)$ 一地震波形データベースの標準的利用システム一, 地 球惑星科学関連学会合同大会予稿集, 76 .

植平賢司・清水 洋・松尾のり道・後藤和彦, 2001, 四 国・中国西端から九州にかけての深発地震面の形状と 発震機構, 月刊地球, 23, 669-673.

上野 寛・畠山信一・明田川保・舟崎 淳 - 浜田信生, 2002 , 気象庁の震源決定方法の改善一浅部速度構造之 重み関数の改良一, 験震時報, 65, 123-134.

Wang, Z. and D. Zhao, 2006, Vp and Vs tomography of Kyushu, Japan: New insight into arc magmatism and forearc seismotectonics, Phys. Earth Planet. Inter., 157, 269-285.

Waldhauser, F. and W. L. Ellsworth, 2000, A DoubleDifference Earthquake Location Algorithm: Method and Application to the Northern Hayward Fault, Calfornia, Bull. Seism. Soc. Am., 90(6), 13531368.

Wessel, P. and W. H. F. Smith, 1995, New version of the Generic Mapping Tools released, EOS Trans. Am. Geophys. Union, 76, 329.

Yamasaki, T. and T. Seno, 2003, Double seismic zone and dehydration embrittlement of the subducting 
slab, J. Geophys. Res., 108, 2212, doi: 10.1029/2002 JB001918.

Yamauchi, M., K. Hirahara, and T. Shibutani, 2003, High resolution receiver function imaging of the seismic velocity discontinuities in the crust and the uppermost mantle beneath southwest Japan, Earth Planets Space, 55, 59-64. 